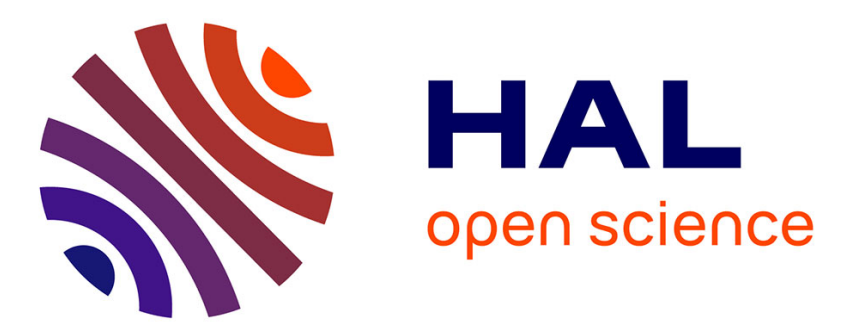

\title{
Islamic Banking and Finance: Recent Empirical Literature and Directions for Future Research
}

Pejman Abedifar, Shahid Ebrahim, Philip Molyneux, Amine Tarazi

\section{To cite this version:}

Pejman Abedifar, Shahid Ebrahim, Philip Molyneux, Amine Tarazi. Islamic Banking and Finance: Recent Empirical Literature and Directions for Future Research. 2014. hal-01073185

\section{HAL Id: hal-01073185 \\ https: / hal-unilim.archives-ouvertes.fr/hal-01073185}

Preprint submitted on 9 Oct 2014

HAL is a multi-disciplinary open access archive for the deposit and dissemination of scientific research documents, whether they are published or not. The documents may come from teaching and research institutions in France or abroad, or from public or private research centers.
L'archive ouverte pluridisciplinaire HAL, est destinée au dépôt et à la diffusion de documents scientifiques de niveau recherche, publiés ou non, émanant des établissements d'enseignement et de recherche français ou étrangers, des laboratoires publics ou privés. 


\title{
Islamic Banking and Finance: Recent Empirical Literature and Directions for Future Research
}

Pejman Abedifar, School of Management, University of St Andrews, The Gateway, North Haugh, St Andrews, Fife, KY16 9RJ, UK: pa31@st-andrews.ac.uk

Shahid Ebrahim, Durham Business School, University of Durham, Mill Hill

Lane,Durham,DH1 3LB, UK: m.s.ebrahim@durham.ac.uk

Philip Molyneux*, Bangor Business School, Bangor University, Wales, LL57 2DG, $U K$ : p.molyneux@bangor.ac.uk

Amine Tarazi, Université de Limoges, LAPE, 5 rue Félix Eboué, 87031 Limoges, France: amine.tarazi@unilim.fr

\begin{abstract}
This paper examines the recent empirical literature in Islamic banking and finance, highlights the main findings and provides a guide for future research. Early studies focus on the efficiency, production technology and general performance features of Islamic versus conventional banks, whereas more recent work looks at profit and loss-sharing (PLS) behaviour, competition, risks as well as other dimensions such as small business lending and financial inclusion. Apart from key exceptions, the empirical literature suggests no major differences between Islamic and conventional banks in terms of their efficiency, competition and risk features (although small Islamic banks are found to be less risky than their conventional counterparts). There is some evidence that Islamic finance aids inclusion and financial sector development. Results from the empirical finance literature, dominated by studies that focus on the risk/return features of mutual funds, finds that Islamic funds perform as well, if not better, than conventional funds - there is little evidence that they perform worse than standard industry benchmarks. Some recent evidence, however, suggests that Islamic bond (Sukuk) issuance destroys value for shareholders.
\end{abstract}

*Corresponding Author 


\section{Introduction}

The key principles underlying Islamic banking and finance - namely the prohibition of Riba (narrowly interpreted as interest) and adherence to other Shariá (Islamic law) requirements - are as ancient as religion itself, although it has only been since the 1960's that banks have offered Islamic financial services. These Shariá compliant services now sum-up to a global industry amounting to around $\$ 2$ trillion in assets, of which $80 \%$ is accounted for by Islamic banks (or Islamic windows of conventional banks), 15\% Sukuk (Islamic bonds), 4\% Islamic mutual funds and 1\% Takaful (Islamic insurance) (The Economist, 2014). According to the Islamic Financial Services Board (2013), Iran is the biggest Islamic banking market (accounting for around 40\% of global Islamic banking assets) followed by Saudi Arabia (14\%), Malaysia (10\%) and the United Arab Emirates (UAE) and Kuwait (both with $9 \%$ shares). There are few countries that have solely Islamic banks - only Iran and Sudan - in the majority of Muslim countries Islamic banks compete head-on with conventional banks. For instance in places such as Saudi Arabia around 35\% of banking sector assets are Shariá compliant, figures are lower for UAE (22\%), Qatar (20\%) and Malaysia (20\%). While Islamic banking and financial assets comprise under $1 \%$ of total global financial assets (given Credit Suisse's (2013) estimates of world financial assets) it is a sector that has grown faster than conventional (Western) finance since the 2007/8 banking crisis, and this trend is expected to continue into the near future (The Economist, 2014). In addition to the growth in banking assets there is increasing competition between major financial centres to take the lead in Sukuk issuance and to develop a broader array of Islamic investment products (TheCityUk 2013). In the light of these developments it is timely to provide a review of the extant literature on Islamic banking and finance to highlight the main areas of interest and futures areas for further research.

\section{A Brief History}

From the earliest stages in Islamic history, Muslims were able to establish a system without interest for mobilizing resources to finance productive activities and consumer needs. The system worked quite effectively during the heyday of Islamic civilization and for centuries thereafter. According to Goitein (1971) partnership and 
profit and loss (PLS) sharing and non-interest based borrowing and lending formed the basis of commerce and industry in twelfth and thirteenth centuries in the Mediterranean region. However, the Protestant Reformation in the Western world provided an impetus to intellectual growth (Hillebrand, 2009). This eventually led to the change in the centre of economic gravity to the West and Western financial institutions (especially banks) became dominant and the Islamic tradition remained dormant. Over the last 50 years or so, however, there has been a revival of interest in developing a modern version of the historic Islamic financial system in the wake of Muslims' desire to stay clear of interest and practice financial transactions consistent with Shariá principles.

When commercial banking emerged after the industrial revolution, Muslim scholars expressed reservations with the Western model of financial intermediation due to its reliance on interest and they called for the development of alternative mechanisms to perform a financial intermediation function in Muslim societies (Iqbal and Molyneux, 2005, Molyneux and Iqbal, 2005). Muslims to a significant extent refrained from dealing with commercial banks. However, the growing needs of traders, industrialists and other entrepreneurs in rapidly monetizing economies were pressing and as a consequence Muslim economists and bankers took up the challenge of developing alternative models of financial intermediation. In the early $19^{\text {th }}$ century most of the Muslim world was under colonial rule. When many of these countries gained their independence after World War II, practical experiments in interest-free financing started at a modest scale and gradually expanded in scope.

While credit societies and cooperatives working on an interest-free basis existed in several Muslim countries even during the colonial period, the semblance of banking institutions started emerging in the early 1960s. A pioneering experiment of putting Islamic principles governing financial dealings into practice was conducted in Mit-Ghamr, Egypt, from 1963-1967. Modelled on the German saving banks (Sparkassen), the Mit-Gamar initiative mobilized small savings from the rural sector largely through savings accounts. No interest was paid to account holders. However, as an incentive they were eligible for small short-term interest-free loans for productive purposes. Account holders were allowed to withdraw their deposits on demand. In addition, investment accounts on the basis of profit and loss sharing were 
also introduced. The funds so mobilized were invested on the basis of PLS with entrepreneurs.

The first interest-free institution with "bank" in its name, Nasser Social Bank, was established in Egypt in 1971. This was the first time a government in a Muslim country provided public support for incorporating an interest-free institution. Even though the objectives of the Nasser Social Bank were mainly social, such as providing interest-free loans to the poor and needy; scholarships to students; and micro-credits to small projects on a PLS basis; the involvement of a public authority in interest-free banking sent important signals to Muslim businessmen having surplus funds. A group of such businessmen established the Dubai Islamic Bank in 1975. This was the first Islamic Bank established on private initiative. However, official support was crucial with the governments of UAE and Kuwait contributing respectively $20 \%$ and $10 \%$ of the capital. (Iqbal and Molyneux, 2005)

Probably one of the most important developments in the history of Islamic banking took place with the establishment of the Islamic Development Bank (IDB) in 1975. The IDB was established as an international financial institution by representatives of member countries of the Organization of the Islamic Conference (OIC) (in 1975 there were 23 members increasing to 57 by 2014). The IDBs main objective is to promote economic and social development in the Muslim world in accordance with the principles of Shariá and it has been a major financier and promoter of an array of Islamic banking and finance initiatives since its formation.

Between 1975 and 1990 the Islamic financial industry developed into an alternative model of financial intermediation. The period was marked by establishment of a substantial number of Islamic financial institutions in the private sector. In addition, governments in three countries, namely, Pakistan, Iran and Sudan, expressed the desire to gradually eliminate interest from their entire economies and substitute it with banking systems based entirely on Islamic principles - by 2014 Iran and Sudan had (virtually) achieved these objectives. Even more important was the fact that several multinational banks started offering Islamic financial products. This was a clear recognition of the viability of the new model and its acceptance by international players. The International Monetary Fund and the World Bank also 
recognized Islamic financial products as alternative means of financial intermediation (Sundararajan and Errico 2002; World Bank, 2013). During the 1990s, while growth in the Islamic banking industry continued, attention was also given to the development of non-bank financial institutions. Islamic financial institutions other than banks started coming on the scene in increasing numbers. These included insurance companies and investment funds although (as noted earlier) the bulk of Islamic financial assets (80\%) are in banking business.

Initiatives for the establishment of some of infrastructure institutions supporting the Islamic financial industry also started in the 1990s. In the beginning, Islamic banking institutions had to work within the institutional framework that supported conventional banking and they were at somewhat of a comparative disadvantage because the institutional framework was not specifically geared to Islamic needs. While still in its infancy, a beginning was made towards constructing a network of supporting institutions for the Islamic financial industry.

Nowadays Islamic banking and finance manifests itself in five ways:

1. Banks and financial institutions operate in countries where the promotion of an Islamic financial system receives active government support;

2. Islamic banks and financial institutions operate in the private corporate sector competing with conventional (Western) institutions;

3. Islamic banking is practiced by conventional commercial banks (via Islamic windows), traditional Islamic banks as well as non-bank financial institutions;

4. Multinational financial institutions (like the Islamic Development Bank in Jeddah) operate on Shariá principles;

5. Islamic capital market instruments (mutual funds, Sukuk), and insurance (Takaful) are becoming more important, for instance, Sukuk issuance partly funded London's Olympic Village and 'Shard' building.

\section{Principles of Islamic Banking \& Finance}

Islamic banking and finance is based on Shariá principles which forbid payment or receipt of Riba generally misconstrued as interest (Pryor, 2007). ${ }^{\mathrm{i}}$ The lending facility encouraged in the medieval era of Islamic society is that of gratuitous loans termed as Qard Al-Hasan. It is interesting to note that Sharia recognizes the time value of money, since according to Islamic rules the price of a good to be sold on 
a deferred payment basis can be different from its current value. ${ }^{\text {ii }}$ While Shariá recognizes excessive payments in business transactions, it prohibits the same on lending activities (Obaidullah, 2005). Islamic finance has evolved based on the precedence of transactions conducted specifically in the medieval era and recorded under Fiqh al-Muamalat. These can mainly be categorized as: 1) Debt-based financing: where the financier purchases or has the underlying assets constructed or purchased and then this is sold to the client at a mark-up. The sale would be on a deferred-payment basis with one or several instalments. 2) Lease-based financing: the financier purchases or has the underlying assets constructed or purchased and then rents it to the client. At the end of the rental period (or proportionate to the rentals) ownership would be transferred wholly or partially to the client. 3) Profit and Loss Sharing (PLS) financing: the financier is the partner of the client and the realized profit or loss would be shared according to pre-agreed proportions (Khan and Ahmed, 2001). The first two Islamic finance methods are collectively known as Non-Profit and Loss Sharing "Non-PLS" contracts.

Besides restrictions on Riba, Shariá has various other prohibitions which have to be taken into account. For instance, according to Shariá all contracts should be free of "Gharar", which is narrowly interpreted as excessive uncertainty. ${ }^{\text {iii }}$ Hence as noted earlier, Islamic financial institutions face some restrictions on application of financial derivatives and other types of contracts (including various forms of insurance policies). In addition, Islamic financial firms are not allowed to undertake business prohibited under Islamic law (known as Haraam) such as investing in companies involved with alcohol, gambling, non-Islamic financial services, pornography, tobacco or weapons. However, as many large firms receive a modest proportion of income from such prohibited activities (for instance, hotel chains and alcohol sales), modern Shariá scholars tend to allow investment in companies with tolerable proportions of revenues from prohibited activities under the condition of Haraam purifcation. This requires investors to donate equivalent proportion of their distributions from such companies to charities to purify their earnings from prohibited activities (Hopener et al 2011). Islamic financial institutions all have Shariá supervisory boards composed of executive management as well as Islamic scholars whose role is to ensure that the firm's activities are undertaken in a Shariá compliant manner. 
It has been suggested that because of the prohibition of interest and the PLS nature of Islamic banking and finance contracts this can make Islamic financing agreements more complex and costly. Generally, in debt-based or lease-based finance, such as Murabaha, Islamic banks arrange for the goods/projects to be purchased and then sell or rent them (at a mark-up) to clients. For purchase/implementation of the goods/projects, Islamic banks normally appoint the client as their agent. Such a framework is somewhat complicated as compared to conventional loan contracts. Sundarajan and Errico (2002) note the specific risks attached to various Non-PLS methods, such as Salam and Ijara. In the former, Islamic banks are exposed to both credit and commodity price risks; in the latter, unlike conventional lease contracts, Islamic banks cannot transfer ownership and therefore have to bear all the risks until the end of the lease period.

Another area of debate relates to the treatment of default penalties. Some jurisdictions rule that such penalties are not authorized by Shariá, so banks make use of rebates instead (Khan and Ahmed, 2001). Here the mark-up on the finance arrangement implicitly covers the return to the banks as well as a default penalty component. If the client repays the loan in a timely manner then they will receive the rebate. While default interest payments are typically calculated over the delayed period in conventional banking, some Islamic banks collect the delayed penalty over the whole financing period. In addition, Islamic banks can also face restrictions regarding the use of derivatives as well as different types of collateral, for instance, they are not authorized to use interest-based assets, like money market instruments or bonds, for security.

In addition to lending, conventional banks also allocate a part of their funds to investments. Such investments normally include purchase of bonds (as well as instruments with shorter maturities) of different types that have risk/return features that help manage portfolio risk. Islamic banks have limited options for such investments since they are not authorized to invest in interest bearing instruments. Alternatively they can invest in Islamic bonds, known as Sukuk. Although (like in short-term Islamic money markets) the asset class still remains relatively underdeveloped, limitations on Islamic bank investment opportunities has been weakened over time due to Haraam purifcation as well as the expansion of alternative Islamic financing instruments. 


\section{Performance of Islamic versus Conventional Banks}

Table 1 illustrates recent empirical literature comparing the performance of Islamic and conventional banks. Most studies use parametric (El-Gamal and Inanoglu, 2002: Majid et al, 2003; Mohamad et al. 2008) or non-parametric frontier approaches (Yudistra, 2004; Bader et al. 2008; Johnes et al 2014) to model cost and profit efficiency (as well as productivity). As the Table illustrates, early studies focus on single countries but more recent literature has been cross-country - Beck, Demirgüç-Kunt and Merrouche (2013) for instance do estimations over 141 countries. Despite the ongoing interest in efficiency comparisons, no strong consensus emerges from this literature, although a (small) majority of studies find no major difference between Islamic and conventional banks in terms of cost and profit efficiency. Fewer studies focus on the determinants of bank profitability (Hassan and Bashir 2003, Rashwan, 2010) and here there is some evidence that better capitalised and loaned-out Islamic banks are more profitable.

\section{<Table 1 Performance of Islamic versus Conventional Banks - Recent Empirical Evidence HERE>}

\section{Risks in Islamic Banking?}

Islamic banking is characterized by features that appear on the one hand to reduce risk: the religious beliefs of clients may induce greater loyalty and discourage default (it may also reduce deposit withdrawal risk). On the other hand it could increase risk due to such factors as: the complexity of Islamic loan contracts, limited default penalties and moral hazard incentives caused by PLS contracts. In terms of insolvency risk, the special relationship with depositors could provide Islamic banks with greater capacity to bear losses yet at the same time, operational limitations on investment and risk management activities could make them less stable than their conventional counterparts. Moreover, while interest is forbidden in Islamic banking, those institutions that compete with conventional banks may be forced to mirror their pricing behaviour and as such may be subject to (indirect) interest rate risk. 
After the global financial crisis in 2007/8 there has been increased interest in risk in banking in general as well as in the Islamic world. Table 2 illustrates the most recent literature.

\section{<Table 2 Risk and Islamic banking HERE>}

Reviewing the literature in Table 2 early studies typically use regression approaches to try and explain various types of risk and to examine differences between conventional and Islamic banks. Čihák and Hesse (2010) and Abedifar et al (2013) examine insolvency risk (using the Z-score measure) as well as other risks and typically find that small Islamic banks have lower default risk compared with small conventional banks. Čihák and Hesse (2010) also find that large Islamic banks are less stable than conventional banks whereas Abedifar et al (2013) and Beck et al (2013) find no such differences. The most recent studies have tended to investigate survivorship of the two types of banks, again cross country, using duration models. Pappas et al (2014), for instance, use duration models and finds that Islamic banks have significantly lower failure rates compared to similar conventional banks. Baele et al (2014) examine 150,000 small business loans (from the Central Bank of Pakistan's Credit Register) over 2006-2008 to examine default rates. They find that the default rate on small business Islamic loans is less than half that of conventional loans. The study also shows that small business borrowers that take on loans from both conventional and Islamic banks are more likely to default on the former - this they put down to the moral pressures linked to religious beliefs. Saeed and Izzeldin (2014) take a different slant looking at the link between profit efficiency (derived from parametric stochastic frontier estimates) and distance to default (derived from a Merton model) and show that for Islamic banks defaults rates are inversely related to profit efficiency whereas there is a positive relationship for their conventional counterparts. Mollah et al (2014) investigate a variety of determinants of Islamic bank risk-taking and they find corporate governance and financial disclosure issues appear to have a major influence.

\section{Other Topical Banking Issues}

\section{i) PLS Versus non-PLS Types of Finance}


As Abedifar et al (2013) note, Islamic banks often tend to deviate from PLS financing principles and operate similarly to conventional banks. Potential deposit withdrawal risk may persuade management to vary from PLS principles by paying competitive returns to investment account holders if they are competing with conventional banks. For instance, Chong and Liu (2009) use Malaysian data to illustrate that investment deposit rates of Islamic banks are closely linked to those of their conventional counterparts. Also when lending Islamic banks are also likely to apply non-PLS principles due to the risks and complexities associated with the PLS method. For instance, under PLS financing, Islamic banks need to determine the profit or loss sharing ratio for each project which can be complicated due to difficulties in quantifying the characteristics of clients and the proposed business opportunity. Revenue is not guaranteed and since they cannot collect collateral from clients, they need to put more effort into selection and monitoring so as to ensure that informational rents are not extracted by borrowers. Hence, for short-term financing, it may not always be viable for Islamic banks to use the PLS method. Moreover, under the Mudarabah contract, Islamic banks have limited means to control and intervene in the management of a project.

There is evidence to suggest that Islamic banks typically do not depend on PLS contracts to undertake their financing activities. Aggarwal and Yousef (2000) show that Islamic banks mainly use Non-PLS instruments to avoid moral hazard problem associated with PLS financing. Chong and Liu (2009) also finds that in Malaysia, only $0.5 \%$ of Islamic bank finance is based on PLS principles and Baele et al (2014) find that the bulk of Islamic financing in Pakistan is not via PLS. According to the Bank Indonesia (2009) PLS modes of finance account for $35.7 \%$ in the financing of Islamic banks operating in the country by the end of 2008 , and this they claim to be the highest proportion in any Islamic banking system.

\section{ii) Competition}

A handful of studies, noticeably Turk Ariss (2010) and Weill (2011), have investigated competition in various countries where Islamic and conventional operate together. The former study uses a variety of indicators - concentration ratios, PanzarRosse H-statistic and Lerner index - to gauge market structure and competition 
issues. The main finding from Turk Ariss (2010) is that Islamic banks are less competitive than conventional operators although this finding conflicts with Weill (2011) who shows that Islamic banks have lower market power. An interesting study by Aysan et al (2014) uses Central Bank of Turkey deposit data to investigate depositor responsiveness to interest changes. Surprisingly, Islamic depositors seem to respond more to deposit rate changes compared to conventional bank depositors - this provides (perhaps) some indirect evidence that Islamic banks on the deposit-side are more competitive.

\section{iii) Small Business Lending and Other Issues}

Other areas covered in the empirical banking literature span a variety of issues. Ongena and Şendeniz-Yüncü (2011) and Shaban et al (2014) analyze the characteristics of Islamic bank business borrowers, concluding that they are dominated by relatively small and young firms that have multiple bank relationships. Islamic banks have a preponderance of such borrowers and they generate relatively high margins. Other studies cover a range of disparate themes ranging from the diffusion of Islamic banking (Imam and Kpodar, 2010) to how Shariá Boards impact bank performance (Mallin et al, 2014) and the link between provisioning and shareholder value creation Elnahass et al (2014). Gheeraert (2014) analyses a sample of 55 countries including 20 Muslim countries during the 2000-2005 period and claims that expansion of Islamic banking fosters banking sector development. Using a similar sample, Gheeraert and Weill (2014) interestingly show a non-linear relationship between Islamic banking development and macroeconomic efficiency Islamic banking aids macroeconomic efficiency up to a point and then restricts it thereafter. Abedifar et al. (2014) explore whether the presence of Islamic commercial banks alongside their conventional counterparts can promote the development of the overall banking sector and economic welfare. Using a sample of 22 Muslim countries with a dual-banking system between 1999 and 2009 they find that the market share of Islamic banks is positively linked to the development of financial intermediation and economic growth, but negatively correlated with income inequality and poverty. They show that the extent and modality of the relationships depends considerably on the institutional environment within which a dual-banking system operates. A summary of the areas discussed in this section are summarised in table 3. 


\section{<Table 3 Other Topical Islamic Banking Issues HERE>}

\section{Islamic Finance}

So far we have discussed the literature that looks at Islamic banking so in this section we outline recent developments in the study of Islamic finance - typically in capital markets areas. The empirical literature is dominated by work that compares the risk and return features of Islamic mutual funds with various benchmarks including conventional and Islamic market indexes as well as portfolios of conventional bonds. The main difference between Islamic funds and their conventional counterparts is that managers have a smaller universe of companies to invest in as they are subject to screening out businesses that are not Shariá compliant - this includes (religious) screening out of companies that operate in areas prohibited under Islamic law and screening out firms that cannot achieve certain financial criteria (for instance, exceeding maximum interest payments on debt deemed permissible). All in all, Islamic fund managers have a more limited investment choice. ${ }^{\text {iv }}$ Recent empirical studies, such as Elfakhani et al (2005), Hayat (2006), Abderrezak (2008), Haddad et al (2009) and Hoepner (2011) find no difference in performance of Islamic equity funds with other conventional funds or index benchmarks. Others, such as Ferdian and Dewi (2007) and Mansor and Bhatti (2011) even find that Islamic funds perform better. There is little evidence that Islamic funds perform worse - Hayatt and Kraeussl (2011) being the exception. A couple of studies have combined efficiency analysis (that tends to dominate the empirical Islamic banking literature) with analysis of fund returns (Saad et al, 2010; and Abdelsalama et al (2014). Saad et al (2010) find that some Islamic funds are more efficient than conventional counterparts and Abdelsalama et al (2014) show that the average socially responsible investment (SRI) fund is more efficient than the average Islamic fund.

A more recent trend has been to examine features of the Islamic bond - Sukuk - market. Cakir and Raei (2007) show that Sukuk returns are not highly correlated with conventional bond returns and therefore present portfolio diversification opportunities (although Derigs and Marzbank, 2009 find no such potential benefits). Both Godlewski et al (2011) and Alam et al (2013) use event study approaches to 
examine investor reaction to Sukuk issuance - they both find evidence of negative market reaction suggesting that investors do not view such activities in a positive light. Finally, Bialkowski et al (2012) also use an event study approach to look at the 'Ramadan effect' - they find that stock returns are higher and less volatile than during the rest of the year. They say, 'Ramadan positively affects investor psychology, as it promotes feelings of solidarity and social identity among Muslims world-wide, leading to optimistic beliefs that extend to investment decisions'(p.835). Table 4 provides a summary of the recent empirical finance literature.

\section{<Table 4 Empirical Evidence from Islamic Finance HERE>}

\section{Conclusion and Future Research}

An extensive empirical literature has emerged over the last decade or so investigating Islamic banking and financial issues. The main finding from this body of works is that Islamic banks are at least as efficient and (particularly for smaller banks) have lower default / insolvency risk than their conventional counterparts. Islamic banks typically focus more on higher margin small business borrowers who are less likely to default. Evidence on market power issues is mixed although there is some evidence that Islamic banks can be more competitive than their conventional counterparts. Other (albeit somewhat limited evidence) suggest that the spread of Islamic banking can aid financial inclusion and economic development. Results from the empirical finance literature, dominated by studies that focus on the risk/return features of mutual funds, finds that Islamic funds generally perform the same or better than conventional funds - there is little evidence that they perform worse than standard industry benchmarks. However, there is some evidence that Sukuk issuance destroys value for shareholders.

Nowadays a broader array of issues are being analysed, including the link between Islamic banking and financial and economic development, the diffusion of Islamic banking, the role of Shariá Supervisory Boards and governance issues, the impact of religious and financial screening on fund performance, and comparisons of Shariá screening with other types of investment filtering - like those for socially 
responsible or environment friendly investments. Much of the governance work is in its infancy, as is the analysis of Sukuk and related instruments. In the banking area there still needs to be work done on examining systemic risks and seeing how this links to Islamic and conventional banking. Also, (as in the conventional empirical banking literature) more work is needed on the features and links between liquidity and market funding risks. There is room for more work to be done on pricing too-bigto fail and other government safety net subsidies in Islamic banking systems, as well as (hypothetical) stress testing of banks in Muslim countries. Can one identify systemically important financial institutions (SIFIs) and measure the risks they pose to the countries and regions in which they operate? Also, as many Islamic institutions are based in the Gulf Cooperation Council (GCC) countries, and as their economies are mainly driven by energy prices, it would be interesting to investigate to what extent such factors influence bank performance and risk? Broader questions should focus on linking financial and social inclusion in the Islamic world and see how this is related to notions of poverty, equality and economic development. Is there a link between health and finance in the Islamic world? These and many more questions pertinent to both the conventional and Islamic banking and financial sectors are worthy (in our view at least) of future academic investigation.

\section{Endnotes}

\footnotetext{
${ }^{\mathrm{i}}$ This misunderstanding ensues from a literal Arabic translation of the word Riba implying an excess or an addition over the amount loaned. Ebrahim et al. (2014a) rationalize this injunction as deterring the employment of financial facilities with endemic agency costs of debt as they lead to expropriation of the assets of either the lender (in case of risk shifting) or that of the borrower (in case of underinvestment). In the context of the recent subprime crisis, Riba can be construed as "toxic" debt that can infect institutions thus impinging on both the real and financial sectors of the economy

ii This legality or permissibility is deduced from the precedence of Prophet Muhammad and his companions. It is also rationalized by religious scholars as emanating from the Qur'ānic verse (2: 275): "God has permitted trade (implying credit sales) and forbidden Riba (implying financial facilities with embedded agency issues). The ramification of this precedence has not been understood from a financial economics perspective until recently. This is explicated by Sen (1998, p. 435) as follows: "when financial markets are imperfect (as in the medieval era of the Prophet and his companions), $a$ seller can find it optimal to offer a menu of deferred payment plans."

iii From a financial economics perspective "Gharar" can be construed as the following. One, it involves market manipulation ensuing from asymmetric information (Thomas, 1995). This definition is consistent with the views of Greenbaum and Thakor (1987) and has credence in the light of the recent market manipulating scandals such as LIBOR fixing, Gold price fixing etc. (http://www.ft.com/indepth/libor-scandal,
} 
http://online.wsj.com/news/articles/SB10001424127887324077704578358381575462340). Two, it involves "trading in risk" (El-Gamal, 2009). This view is consistent with that of Claessens et al. (2012).

iv Shariá screening has been found to tilt a portfolio towards 'growth' stocks with the exclusion of value stocks. This leads to a style bias impacting on the long term performance of the portfolio (Ebrahim et al, 2014b).

\section{References}

Abdelsalama, O. Duygun, M.F. Matallín-Sáez, J.C and Tortosa-Ausina, E. (2014) On the comparative performance of socially responsible and Islamic mutual funds, Journal of Economic Behavior and Organization 103, Supplement Special Issue on Islamic Finance, (July): S108-S128

Abdelsalam, O. Duygun, M.F. Matallín-Sáez, J.C. and Tortosa-Ausina, E. (2014) Do ethics imply persistence? The case of Islamic and socially responsible funds, Journal of Banking and Finance 40 (3): 182-194

Abderrezak, F. (2008) The Performance of Islamic Equity Funds: A Comparison to Conventional, Islamic and Ethical Benchmarks. PhD Thesis, Department of Finance, University of Maastricht, Netherlands.

Abdul-Majid, M. Saal, D.S. and Battisti, G. (2010) Efficiency in Islamic and conventional banking: An international comparison, Journal of Productivity Analysis 34(1): 25-43.

Abdul-Majid, M. Saal, D.S., Battisti, G. (2011a) Efficiency and total factor productivity change of Malaysian commercial banks. Service Industries Journal 31(13): 2117-2143.

Abdul-Majid, M. Saal, D.S., Battisti, G. (2011b) The impact of Islamic banking on the cost efficiency and productivity change of Malaysian commercial banks. Applied Economics 43 (16): 2033-3054.

Abdullah, F., Hassan, T. and Mohamad, S. (2007) Investigation of the performance of Malaysian Islamic unit trust funds. Managerial Finance 33 (2): 142-153.

Abedifar, P., Molyneux, P. and Tarazi, A. (2013) Risk in Islamic banking, Review of Finance 17 (6): 2035-2096.

Abedifar, P., Hasan, I. and Tarazi, A. (2014) Finance-growth nexus and dual-banking systems: Relative importance of Islamic banks, University of Limoges Working Paper.

Aggarwal, R.K. and Yousef, T. (2000) Islamic banks and investment financing, Journal of Money, Credit and Banking 32 (1): 93-120. 
Alam, N. Hassan, M.K and Haque, M.A. (2013) Are Islamic bonds different from conventional bonds? International evidence from capital market tests, Borsa Istanbul Review, 13 (3): 22-29.

Al-Jarrah, I. and Molyneux, P. (2005) Efficiency in Arabian banking, in: M. Iqbal and R. Wilson (eds.), Islamic Perspectives on Wealth Creation, Chapter 6, pp 97-117, Edinburgh: Edinburgh University Press.

Aysan, A.F. Disli, M. and Oztur, H. (2014) The impact of religious commitment on Islamic bank depositors: Does size matter? Paper presented at a seminar on Finance and Development in Muslim Economies, sponsored by Islamic Research Training Institute (IRTI), Islamic Development Bank and the Journal of Financial Services Research, 15 September, Bangor University, UK

Azmat, S. Skully, M. and Brown, K (2014) Credit risk in Islamic joint venture bond' Journal of Economic Behavior and Organization 103, Supplement Special Issue on Islamic Finance, (July): S129-S145

Bader, M. K. I., Mohamad, S., Ariff, M. and Hassan, T. (2008) Cost, revenue and profit efficiency of Islamic versus conventional banks: International evidence using Data Envelopment Analysis. Islamic Economic Studies 15 (2): 23-76.

Baele, L. Farooq, M. and Ongena, S. (2014) Of religion and redemption: Evidence from default on Islamic loans Journal of Banking and Finance 44 (6):141-159.

Bank Indonesia Report (2009) The Lack of Profit-and-Loss Sharing Financing in Indonesia's Islamic Banks: Revisited, Center of Education and Central Banking Studies, Bank Indonesia, Jakarta, Indonesia.

Bashir, A. (1999) Risk and profitability measures in Islamic banks: The case of two Sudanese banks, Islamic Economic Studies 6 (2): 1-24.

Beck, T., Demirgüc-Kunt, A. and Merrouche, O. (2013) Islamic vs. conventional banking: business model, efficiency and stability. Journal of Banking and Finance 37 (2): 433-447.

Białkowski, J. Etebari, A. and Wisniewski, T.P (2012) Fast profits: Investor sentiment and stock returns during Ramadan', Journal of Banking and Finance 36 (3): 835-845

Cakir, S and Raei, F. (2007) Sukuk vs. Eurobonds: Is there a difference in Value-atRisk? International Monetary Fund Working Paper, WP/07/237, October, Washington DC: IMF

Chong, B.S. and Liu, M.H. (2009) Islamic banking: Interest-free or interest-based? Journal of Pacific-Basin Finance 17 (1): 125-144.

Čihák, M. and Hesse, H. (2010) Islamic banks and financial stability: An empirical analysis. Journal of Financial Services Research 38 (2): 95-113. 
Claessens, S. Pozsar Z. Ratnovski L. and Singh M. (2012) Shadow Banking: Economics and Policy. International Monetary Fund Staff Discussion Note SDN/12/12, Washington DC: IMF

Credit Suisse (2013) Global Wealth Databook. Credit Suisse Research Institute, Zurich: Credit Suisse. Available at: https://publications.creditsuisse.com/tasks/render/file/?fileID=1949208D-E59A-F2D9-6D0361266E44A2F8

Derigs, U. and Marzban, S. (2008) Review and analysis of current Shariah-compliant equity screening practices. International Journal of Islamic and Middle Eastern Finance and Management 1 (4): 285-303.

Ebrahim M.S. Jaafar A. Molyneux, P. and Salleh, M.O. (2014a). Agency costs, financial contracting and the Muslim world. Working Paper. Durham University Business School, University of Durham, UK.

Ebrahim M.S. Hudson, R. and Shah, E. (2014b). Taxes and the value-growth puzzle. Working Paper. Durham University Business School, University of Durham, UK.

Economist, The (2014) Islamic finance, Big interest, no interest, 412 (8904) September 13, 75-76.

Elfakhani, S. Hassan, M.K and Sidani, Y. (2005) Comparative performance of Islamic versus secular mutual funds. Presentation at the Economic Research Forum Conference in Cairo, Egypt, May, 19-21

El-Gamal, M.A and Inanoglu, H. (2002) Efficiencies and unobserved heterogeneity in Turkish banking: 1990-2000, unpublished working paper, Rice University, Department of Economics.

El-Gamal, M.A. (2009) Islamic Finance: Law, Economics and Practice. NY: Cambridge University Press.

Elnahass, M, Izzeldin, M. and Abdelsalam, O. (2014) Loan loss provisions, bank valuations and discretion: A comparative study between conventional and Islamic banks, Journal of Economic Behavior and Organization 103, Supplement Special Issue on Islamic Finance, (July): S160-S173.

Ferdian, I. and Dewi, M. (2007) The performance analysis of Islamic mutual funds A comparative study between Indonesia and Malaysia. Presentation at the International Conference on Islamic Capital Markets, August 27-29, Jakarta, Indonesia.

Gheeraert, L. and Weill, L. (2014) Does Islamic banking development favour macroeconomic efficiency? Evidence on the Islamic finance-growth nexus., Laboratoire de Recherche en Gestion \& Economie Working Paper 2014-04. University of Strasbourg, Strasbourg: LaRGE. 
Gheeraert, L. (2014) Does Islamic finance spur banking sector development? Journal of Economic Behavior and Organization 103, Supplement Special Issue on Islamic Finance, (July): S4-S20

Godlewski, C. J, Turk Ariss, R. and L. Weill (2010) 'Are Islamic Investment Certificates Special? Evidence on the Post-Announcement Performance of Sukuk Issues', Laboratoire de Recherche en Gestion et Economie Working Paper2010-05, University of Strasbourg, Strasbourg: LaRGE.

Goitein, S. D. (1971) A Mediterranean Society, Berkeley and Los Angeles: University of California Press.

Greenbaum, S.I. and Thakor, A.V. (1987) Bank funding modes: Securitization versus deposits. Journal of Banking and Finance 11(3): 379-401.

Haddad, M. Homaifar,G. Elfakhani, S. and Ahmedov, H. (2009) Intertemporal test of beta stationarity performance of Islamic sector structured mutual funds. Journal for International Business and Entrepreneurship Development 4 (4): 275-285.

Hassan, M.K. and Bashir, A. (2003) Determinants of Islamic banking profitability, paper presented at the Economic Research Forum (ERF) Tenth Annual Conference, Marrakesh, Morocco, 16-18 December.

Hassan, M.K and Dridi, J. (2010) The effects of the global crisis on Islamic and conventional banks: A comparative study, International Monetary Fund Working Paper No. 10/201, Washington DC: IMF

Hassan, M.K, Yu, J-S, and Kim, D-W. (2014) Financial inclusion and economic growth in OIC countries. Paper presented at the seminar on Finance and Development in Muslim Economies, sponsored by Islamic Research Training Institute (IRTI), Islamic Development Bank and the Journal of Financial Services Research, 15 September, Bangor University, UK

Hayat, R. (2006). An empirical assessment of Islamic equity fund returns. Failaka website: 1-69 (also at http://www.kantakji.com/media/7134/70093.pdf)

Hayat, R. and Kraeussl, R. (2012) Risk and return characteristics of Islamic equity funds. Emerging Markets Review 12 (2): 189-203.

Hillebrand, H. J. (2009). Editor, The Protestant Reformation, Revised Edition, NY: Harper Perennial.

Hoepner, A. Rammal, H and Rezec, M. (2011) Islamic mutual funds' financial performance and international investment style: evidence from 20 countries. The European Journal of Finance 17 (9-10): 829-850. 
Imam, P. and Kpodar, K. (2010) Islamic banking: How has it diffused? International Monetary Fund Working Paper No. 10/195, Washington DC: IMF.

Iqbal, M and Molyneux, P. (2005) Thirty Years of Islamic Banking. London: Palgrave Macmillan.

Islamic Financial Services Board (2013) Islamic Financial Services Industry Stability Report, IFSB Bank Negara Malaysia: Kuala Lumpur.

Ismail, A. and Shakrani, M.S. (2003) The conditional CAPM and cross-sectional evidence of return and beta for Islamic unit trusts in Malaysia. Journal of Economics and Management 11 (1): 1-31.

Johnes, J. Izzeldin, M. and Pappas, V. (2009) The efficiency of Islamic and conventional banks in the Gulf Cooperation Council (GCC) countries: an analysis using financial ratios and Data Envelopment Analysis. Lancaster University

Management School Working Paper 2009/023. Lancaster UK: Lancaster University.

Johnes, J, Izzeldin, M and Pappas, V (2014) A comparison of performance of Islamic and conventional banks 2004-2009, Journal of Economic Behavior and Organization 103, Supplement Special Issue on Islamic Finance, (July): S93-S107

Khan, T. and Ahmed, H. (2001) Risk management: An analysis of issues in Islamic financial industry, Islamic Development Bank Occasional Paper No. 5, Islamic Research Training Institute, Jeddah: Islamic Development Bank

Majid, A. M. Nor, N.G. and Said, F.F. (2003) Efficiency of Islamic banks in Malaysia, Paper presented to the Fifth International Conference on Islamic Economics and Banking, Bahrain, October, 7-9.

Mallin, C, Farag, H and Ow-Yong, K (2014) Corporate social responsibility and financial performance in Islamic banks, Journal of Economic Behavior and Organization 103, Supplement Special Issue on Islamic Finance, (July): S21-S38

Mansor, F. and Bhatti, M. (2011) Islamic mutual funds performance for emerging markets, during bullish and bearish periods: The case of Malaysia. Paper presented at the 2nd International Conference on Business and Economic Research. 14-16 March, Langkawi, Kedah, Malaysia

Mohamad, S. Hassan, T. and Bader, M.K.I. (2008) Efficiency of conventional versus Islamic banks: International evidence using the stochastic frontier approach (SFA). Journal of Islamic Economics, Banking and Finance 4 (2): 107-130.

Mollah, S, Hassan, M.K and Al Farooque, O. (2014) Corporate governance, risktaking and firm performance of Islamic banks during the global financial crisis, Paper presented at the seminar on Finance and Development in Muslim Economies, 
sponsored by Islamic Research Training Institute (IRTI), Islamic Development Bank and the Journal of Financial Services Research, 15 September, Bangor University, UK.

Molyneux, P and Iqbal M, (2005) Arab Banking and Financial Systems, London: Palgrave Macmillan.

Obaidullah, M. (2005) Islamic financial services, Islamic Economics Research Center, Occasional Paper 158, King Abdulaziz University, Jeddah, Saudi Arabia.

Ongena, S. and Şendeniz-Yüncü, İ. (2011) Which firms engage small, foreign, or state banks? And who goes Islamic? Evidence from Turkey, Journal of Banking and Finance 35 (12): 3213-3224.

Pappas, V, Ongena, S. Izzeldin, M and Fuertes, A-M (2014) Do Islamic banks 'Live free and die harder'?, Paper presented at the seminar on Finance and Development in Muslim Economies, sponsored by Islamic Research Training Institute (IRTI), Islamic Development Bank and the Journal of Financial Services Research, 15 September, Bangor University, UK.

Pryor, F.L. (2007) The economic impact of Islam on developing countries. World Development 35 (11): 1815-1835.

Rashwan, M. H. (2010) A comparison between Islamic and traditional banks: Pre and post the 2008 financial crisis, Available at SSRN: http://ssrn.com/abstract=1724451 or doi:10.2139/ssrn. 1724451 .

Razzaq, N. Gul, S. Sajid, M and Mughal, S. (2012) Performance of Islamic mutual funds in Pakistan. Economic and Finance Review 2 (3): 16-25.

Saad, N., Majid, M. Kassim, S. Hamid, Z and Yusof, R. (2010) A comparative analysis of the performance of conventional and Islamic unit trust companies in Malaysia. International Journal of Managerial Finance 6 (1): 24-47.

Saeed, M. and Izzeldin, M (2014) Examining the relationship between default risk and efficiency in Islamic and conventional banks, Journal of Economic Behavior and Organization (forthcoming)

Samad, A. (1999) Comparative efficiency of the Islamic bank vis-à-vis conventional banks in Malaysia, IIUM Journal of Economics and Management 7 (1): 1-25.

Sen, A. (1998) Seller financing of consumer durables, Journal of Economics and Management Strategy 7 (3): 435-460.

Shaban, M, Duygun, M. Anwar, M and Akbar, B (2014) Diversification and banks' willingness to lend to small businesses: Evidence from Islamic and conventional 
banks in Indonesia, Journal of Economic Behavior and Organization 103, Supplement Special Issue on Islamic Finance, (July): S39-S55

Sundararajan, V. and Errico, L. (2002) Islamic financial institutions and products in the global financial system: Key issues in risk management and challenges ahead. International Monetary Fund Working Paper WP/02/192. Washington DC: IMF.

TheCityUK (2013), Islamic Finance, London: TheCityUK. Available at http://www.thecityuk.com/research/our-work/reports-list/islamic-finance-2013/

Thomas, A.S. (1995) What is Permissible Now!? Singapore: Muslim Converts' Association of Singapore.

Turk Ariss, R. (2010) Competitive conditions in Islamic and conventional banking: A global perspective, Review of Financial Economics 19 (3): 101-108.

Weill, L. (2011) Do Islamic banks have greater market power? Comparative Economic Studies 53 (2): 291-306.

World Bank (2013) Economic Development and Islamic Finance, Editors: Z. Iqbal and A. Mirakhor, July, Washington DC: World Bank.

http://dx.doi.org/10.1596/978-0-8213-9953-8

Yudistra. D. (2004) Efficiency in Islamic banking: An empirical analysis of eighteen banks, Islamic Economic Studies 12 (1), 1-19. 
Table 1 Performance of Islamic versus Conventional Banks - Recent Empirical Evidence

\begin{tabular}{|c|c|c|c|c|c|c|}
\hline Authors & $\begin{array}{l}\text { Country(ies) of } \\
\text { Study }\end{array}$ & Period & $\begin{array}{l}\text { Data } \\
\text { Type }\end{array}$ & $\begin{array}{l}\text { Research } \\
\text { Focus }\end{array}$ & Methodology & Main Finding \\
\hline Bashir (1999) & Sudan & $\begin{array}{l}1979- \\
1993\end{array}$ & $\begin{array}{l}\text { Yearly bank- } \\
\text { level } \\
\text { accounting } \\
\text { data }\end{array}$ & $\begin{array}{l}\text { Asset size and } \\
\text { bank } \\
\text { performance }\end{array}$ & $\begin{array}{l}\text { Regression - } \\
\text { OLS }\end{array}$ & $\begin{array}{l}\text { Larger banks are more profitable yet } \\
\text { have higher leverage. Analysis is } \\
\text { based on only two Islamic banks. }\end{array}$ \\
\hline Samad (1999) & Malaysia & $\begin{array}{l}1992- \\
1996\end{array}$ & $\begin{array}{l}\text { Yearly bank- } \\
\text { level } \\
\text { accounting } \\
\text { data }\end{array}$ & Cost efficiency & $\begin{array}{l}\text { Descriptive } \\
\text { statistics and } \\
\text { ANOVA }\end{array}$ & $\begin{array}{l}\text { Islamic banks are more efficient than } \\
\text { their conventional counterparts. }\end{array}$ \\
\hline $\begin{array}{l}\text { El-Gamal and } \\
\text { Inanoglu } \\
(2002)\end{array}$ & Turkey & $\begin{array}{l}1990- \\
2000\end{array}$ & $\begin{array}{l}\text { Yearly bank } \\
\text { level } \\
\text { accounting } \\
\text { data }\end{array}$ & $\begin{array}{l}\text { Production } \\
\text { technology }\end{array}$ & $\begin{array}{l}\text { Stochastic } \\
\text { Frontier } \\
\text { Analysis }\end{array}$ & $\begin{array}{l}\text { Islamic banks have a similar } \\
\text { production technology } \\
\text { conventional commercial banks. }\end{array}$ \\
\hline $\begin{array}{l}\text { Majid et al } \\
\text { (2003) }\end{array}$ & Malaysia & $\begin{array}{l}1993- \\
2000\end{array}$ & $\begin{array}{l}\text { Yearly bank } \\
\text { level } \\
\text { accounting } \\
\text { data }\end{array}$ & Cost efficiency & $\begin{array}{l}\text { Stochastic } \\
\text { Frontier } \\
\text { Analysis }\end{array}$ & $\begin{array}{l}\text { No statistically significant difference } \\
\text { in the level of efficiency between } \\
\text { Islamic and conventional banks and } \\
\text { no evidence to suggest that } \\
\text { ownership influences cost efficiency. }\end{array}$ \\
\hline $\begin{array}{l}\text { Hassan and } \\
\text { Bashir (2003) }\end{array}$ & $\begin{array}{l}\text { Islamic banks } \\
\text { operating in } 21 \\
\text { countries }\end{array}$ & $\begin{array}{l}1994- \\
2001\end{array}$ & $\begin{array}{l}\text { Yearly bank } \\
\text { level } \\
\text { accounting } \\
\text { data }\end{array}$ & $\begin{array}{l}\text { Determinants of } \\
\text { bank } \\
\text { profitability } \\
\text { (ROA, ROE, } \\
\text { NIM) }\end{array}$ & $\begin{array}{l}\text { Regression - } \\
\text { GLS }\end{array}$ & $\begin{array}{l}\text { Controlling for macroeconomic } \\
\text { environment, financial market } \\
\text { structure, and taxation, the results } \\
\text { indicate that high capital and loan- } \\
\text { to-asset ratios lead to higher } \\
\text { profitability (as does favorable } \\
\text { macroeconomic conditions). }\end{array}$ \\
\hline $\begin{array}{l}\text { Yudistra } \\
(2004)\end{array}$ & $\begin{array}{l}\text { Islamic banks } \\
\text { operating in } \\
12 \text { countries }\end{array}$ & $\begin{array}{l}1997- \\
2000\end{array}$ & $\begin{array}{l}\text { Yearly bank } \\
\text { level } \\
\text { accounting } \\
\text { data }\end{array}$ & $\begin{array}{l}\text { Technical and } \\
\text { scale efficiency }\end{array}$ & $\begin{array}{l}\text { Data } \\
\text { Envelopment } \\
\text { Analysis (DEA) } \\
\text { and OLS } \\
\text { regression }\end{array}$ & $\begin{array}{l}\text { Islamic bank inefficiencies appear } \\
\text { relatively low (around 10\%) } \\
\text { compared with those for } \\
\text { conventional banks derived from } \\
\text { other studies. Small to medium-sized } \\
\text { Islamic banks exhibit diseconomies } \\
\text { of scale. Islamic banks in the Middle } \\
\text { East are less efficient than those } \\
\text { operating outside the region. }\end{array}$ \\
\hline $\begin{array}{l}\text { Al-Jarrah and } \\
\text { Molyneux } \\
(2005)\end{array}$ & $\begin{array}{l}\text { Bahrain, Egypt, } \\
\text { Jordan and } \\
\text { Saudi Arabia }\end{array}$ & $\begin{array}{l}1992- \\
2000\end{array}$ & $\begin{array}{l}\text { Yearly bank } \\
\text { level } \\
\text { accounting } \\
\text { data }\end{array}$ & $\begin{array}{l}\text { Cost and profit } \\
\text { efficiency }\end{array}$ & $\begin{array}{l}\text { Stochastic } \\
\text { Frontier } \\
\text { Analysis }\end{array}$ & $\begin{array}{l}\text { Islamic banks are found to be the } \\
\text { most cost and profit efficient banks } \\
\text { compared to conventional } \\
\text { commercial and investment banks. }\end{array}$ \\
\hline $\begin{array}{l}\text { Mohamad et } \\
\text { al. (2008) }\end{array}$ & $\begin{array}{l}21 \text { Organization } \\
\text { of Islamic } \\
\text { Conference } \\
\text { (OIC) countries }\end{array}$ & $\begin{array}{l}1990- \\
2005\end{array}$ & $\begin{array}{l}\text { Yearly bank } \\
\text { level } \\
\text { accounting } \\
\text { data }\end{array}$ & $\begin{array}{l}\text { Cost and profit } \\
\text { efficiency }\end{array}$ & $\begin{array}{l}\text { Stochastic } \\
\text { Frontier } \\
\text { Analysis }\end{array}$ & $\begin{array}{l}\text { No significant difference between } \\
\text { cost and profit efficiency of } \\
\text { conventional versus Islamic banks, } \\
\text { irrespective of size, age and } \\
\text { geographical location Islamic banks } \\
\text { based in the Middle East and } \\
\text { Turkey are more cost efficient than } \\
\text { their African counterparts. }\end{array}$ \\
\hline $\begin{array}{l}\text { Bader et al. } \\
(2008)\end{array}$ & $\begin{array}{l}21 \text { OIC } \\
\text { countries }\end{array}$ & $\begin{array}{l}1995- \\
2005\end{array}$ & $\begin{array}{l}\text { Yearly bank } \\
\text { level } \\
\text { accounting } \\
\text { data }\end{array}$ & $\begin{array}{l}\text { Cost, revenue } \\
\text { and profit } \\
\text { efficiency }\end{array}$ & $\begin{array}{l}\text { Data } \\
\text { Envelopment } \\
\text { Analysis }\end{array}$ & $\begin{array}{l}\text { No significant difference between } \\
\text { cost, revenue and profit efficiency of } \\
\text { conventional versus Islamic banks. } \\
\text { Note this study uses the same sample } \\
\text { as Mohamed et al (2008). }\end{array}$ \\
\hline $\begin{array}{l}\text { Abdul-Majid } \\
\text { et al. (2010) }\end{array}$ & 10 countries & $\begin{array}{l}1996- \\
2002\end{array}$ & $\begin{array}{l}\text { Yearly bank } \\
\text { level } \\
\text { accounting } \\
\text { data }\end{array}$ & $\begin{array}{l}\text { Returns to scale } \\
\text { and efficiency }\end{array}$ & $\begin{array}{l}\text { Parametric } \\
\text { output distance } \\
\text { function }\end{array}$ & $\begin{array}{l}\text { Islamic banks are found to have } \\
\text { moderately higher returns to scale } \\
\text { than conventional banks but appear } \\
\text { less efficient due to Sharia } \\
\text { compliance. Country effects have a } \\
\text { significant impact on efficiency } \\
\text { differences. }\end{array}$ \\
\hline $\begin{array}{l}\text { Johnes et al } \\
(2009)\end{array}$ & $\begin{array}{l}\mathrm{GCC}- \\
\text { 6countries }\end{array}$ & $\begin{array}{l}2004- \\
2007\end{array}$ & $\begin{array}{l}\text { Yearly bank } \\
\text { level } \\
\text { accounting } \\
\text { data }\end{array}$ & $\begin{array}{l}\text { Efficiency and } \\
\text { productivity }\end{array}$ & $\begin{array}{l}\text { DEA } \\
\text { Malmquist } \\
\text { productivity } \\
\text { Ratio Analysis }\end{array}$ & $\begin{array}{l}\text { Islamic banks have (significantly) lower } \\
\text { efficiency than conventional banks. } \\
\text { Modest productivity growth over the study } \\
\text { period. }\end{array}$ \\
\hline $\begin{array}{l}\text { Rashwan } \\
\text { (2010) }\end{array}$ & 15 countries & $\begin{array}{l}2007- \\
2009\end{array}$ & $\begin{array}{l}\text { Bank level } \\
\text { data }\end{array}$ & $\begin{array}{l}\text { Profitability and } \\
\text { efficiency over } \\
\text { the banking } \\
\text { crisis }\end{array}$ & $\begin{array}{l}\text { Multivariate } \\
\text { analysis of } \\
\text { variance } \\
\text { (MANOVA) }\end{array}$ & $\begin{array}{l}\text { Islamic banks are more profitable } \\
\text { and efficient than traditional banks } \\
\text { pre-crisis but the opposite is the case } \\
\text { post-crisis. }\end{array}$ \\
\hline $\begin{array}{l}\text { Abdul-Majid } \\
\text { et al. } \\
\text { (2011a,b) }\end{array}$ & Malaysia & $\begin{array}{l}1996- \\
2002\end{array}$ & $\begin{array}{l}\text { Bank level } \\
\text { data }\end{array}$ & $\begin{array}{l}\text { Efficiency and } \\
\text { productivity }\end{array}$ & $\begin{array}{l}\text { Stochastic } \\
\text { Frontier } \\
\text { Analysis }\end{array}$ & $\begin{array}{l}\text { Islamic banks and Islamic window } \\
\text { banks are less cost efficient than } \\
\text { their conventional counterparts }\end{array}$ \\
\hline
\end{tabular}




\begin{tabular}{|c|c|c|c|c|c|c|}
\hline $\begin{array}{l}\text { Beck, } \\
\text { Demirgüç- } \\
\text { Kunt and } \\
\text { Merrouche } \\
(2013) \\
\end{array}$ & $\begin{array}{l}141 \text { countries } \\
\text { (including } 22 \\
\text { OIC member } \\
\text { countries) }\end{array}$ & $\begin{array}{l}1995- \\
2007\end{array}$ & $\begin{array}{l}\text { Yearly bank- } \\
\text { level } \\
\text { accounting } \\
\text { data }\end{array}$ & $\begin{array}{l}\text { Efficiency, asset } \\
\text { quality, stability } \\
\text { and business } \\
\text { orientation }\end{array}$ & $\begin{array}{l}\text { Regression - } \\
\text { OLS Fixed } \\
\text { effects, Robust }\end{array}$ & $\begin{array}{l}\text { Few significant differences are } \\
\text { found between } \\
\text { conventional banks. }\end{array}$ \\
\hline $\begin{array}{l}\text { Johnes et al } \\
\text { (2014) }\end{array}$ & $\begin{array}{l}\text { Countries } \\
\text { where at least } \\
60 \% \text { of the } \\
\text { population is } \\
\text { Muslim - } 18 \\
\text { countries. }\end{array}$ & $\begin{array}{l}2004- \\
2009\end{array}$ & $\begin{array}{l}\text { Yearly bank- } \\
\text { level } \\
\text { accounting } \\
\text { data }\end{array}$ & Efficiency & $\begin{array}{l}\text { DEA, meta- } \\
\text { frontier, Two- } \\
\text { stage approach } \\
\text { examining } \\
\text { determinants of } \\
\text { efficiency }\end{array}$ & $\begin{array}{l}\text { Islamic banks are less efficient, in } \\
\text { general, than their conventional } \\
\text { counterparts }\end{array}$ \\
\hline
\end{tabular}

Source: Adapted from Abedifar et al (2013) Table 1 and authors updates 


\section{Table 2 Risk and Islamic Banking}

\begin{tabular}{|c|c|c|c|c|c|c|}
\hline Authors & $\begin{array}{l}\text { Country(ies) of } \\
\text { Study }\end{array}$ & Period & Data Type & Research Focus & Methodology & Main Finding \\
\hline $\begin{array}{l}\text { Čihák and } \\
\text { Hesse (2010) }\end{array}$ & $\begin{array}{l}20 \text { OIC } \\
\text { member } \\
\text { countries }\end{array}$ & $\begin{array}{l}1993- \\
2004\end{array}$ & $\begin{array}{l}\text { Yearly bank- } \\
\text { level } \\
\text { accounting } \\
\text { data }\end{array}$ & Insolvency risk & $\begin{array}{l}\text { Regression - } \\
\text { OLS and } \\
\text { Robust }\end{array}$ & $\begin{array}{l}\text { Small Islamic banks are more } \\
\text { stable than small conventional } \\
\text { banks; however, large Islamic } \\
\text { banks are less stable than their } \\
\text { conventional counter-parts. }\end{array}$ \\
\hline $\begin{array}{l}\text { Hasan and } \\
\text { Dridi (2010) }\end{array}$ & 8 countries & $\begin{array}{l}2007- \\
2009\end{array}$ & $\begin{array}{l}\text { Yearly bank- } \\
\text { level } \\
\text { accounting } \\
\text { data }\end{array}$ & $\begin{array}{l}\text { Factors } \\
\text { influencing } \\
\text { performance, } \\
\text { growth and ratings } \\
\text { over crisis period }\end{array}$ & $\begin{array}{l}\text { Regression - } \\
\text { OLS }\end{array}$ & $\begin{array}{l}\text { The credit and asset growth of } \\
\text { Islamic banks was more than that } \\
\text { of conventional banks from } 2008 \\
\text { to } 2009 \text { 'contributing to financial } \\
\text { and economic stability', although } \\
\text { profits of Islamic banks fell more } \\
\text { than conventional banks in } 2009 \\
\text { due to limitations in their risk } \\
\text { management practices }\end{array}$ \\
\hline $\begin{array}{l}\text { Abedifar et al } \\
\text { (2013) }\end{array}$ & $\begin{array}{l}24 \text { OIC } \\
\text { member } \\
\text { countries }\end{array}$ & $\begin{array}{l}1999- \\
2009\end{array}$ & $\begin{array}{l}\text { Yearly bank- } \\
\text { level } \\
\text { accounting } \\
\text { data }\end{array}$ & $\begin{array}{l}\text { Credit risk, } \\
\text { insolvency risk, } \\
\text { interest rate risk } \\
\text { and possibility of } \\
\text { extracting } \\
\text { religious rent }\end{array}$ & $\begin{array}{l}\text { Regression - } \\
\text { random effects }\end{array}$ & $\begin{array}{l}\text { Islamic banks that are small, } \\
\text { leveraged and based in countries } \\
\text { with predominantly Muslim } \\
\text { populations have lower credit risk } \\
\text { than conventional banks. Small } \\
\text { Islamic banks appear more stable } \\
\text { than similar sized conventional } \\
\text { banks. During the recent crisis, } \\
\text { however, large Islamic banks } \\
\text { exhibit lower stability than large } \\
\text { conventional banks Implicit } \\
\text { interest income and expense, as } \\
\text { well as credit risk of Islamic banks } \\
\text { are less responsive to domestic } \\
\text { interest rates. Islamic banks do not } \\
\text { seem to charge special rents to } \\
\text { their clients for offering Sharia } \\
\text { compliant financial products. }\end{array}$ \\
\hline $\begin{array}{l}\text { Beck et al } \\
\text { (2013) }\end{array}$ & $\begin{array}{l}141 \text { countries } \\
\text { (including } 22 \\
\text { OIC member } \\
\text { countries) }\end{array}$ & $\begin{array}{l}1995- \\
2007\end{array}$ & $\begin{array}{l}\text { Yearly bank- } \\
\text { level } \\
\text { accounting } \\
\text { data }\end{array}$ & $\begin{array}{l}\text { Efficiency, asset } \\
\text { quality, stability } \\
\text { and business } \\
\text { orientation }\end{array}$ & $\begin{array}{l}\text { Regression - } \\
\text { OLS Fixed } \\
\text { effects, Robust }\end{array}$ & $\begin{array}{l}\text { Few significant differences are } \\
\text { found between Islamic and } \\
\text { conventional banks. }\end{array}$ \\
\hline $\begin{array}{l}\text { Pappas et al } \\
(2014)\end{array}$ & 20 countries & $\begin{array}{l}1995- \\
2010\end{array}$ & $\begin{array}{l}\text { Yearly bank- } \\
\text { level } \\
\text { accounting } \\
\text { data }\end{array}$ & $\begin{array}{l}\text { Survival rates of } \\
\text { Islamic and } \\
\text { conventional } \\
\text { banks }\end{array}$ & $\begin{array}{l}\text { Duration } \\
\text { models, hazard } \\
\text { rates }\end{array}$ & $\begin{array}{l}\text { Islamic banks have a significantly } \\
\text { lower risk of failure both } \\
\text { unconditionally } \\
\text { and conditionally on time-varying } \\
\text { bank characteristics, market } \\
\text { structure and macro-economic } \\
\text { conditions. }\end{array}$ \\
\hline $\begin{array}{l}\text { Baele et al } \\
(2014)\end{array}$ & Pakistan & $\begin{array}{l}2006: 04 \\
- \\
2008: 12\end{array}$ & $\begin{array}{l}150,000 \\
\text { Monthly } \\
\text { business loans }\end{array}$ & Loan default rate & Hazard function & $\begin{array}{l}\text { Default rate of Islamic loans is less } \\
\text { than half the default rate of } \\
\text { conventional loans. } \\
\text { Islamic loans are less likely to } \\
\text { default during Ramadan }\end{array}$ \\
\hline $\begin{array}{l}\text { Saeed and } \\
\text { Izzeldin } \\
(2014)\end{array}$ & $\begin{array}{l}\text { Bahrain, } \\
\text { Bangladesh, } \\
\text { Indonesia, } \\
\text { Kuwait, } \\
\text { Pakistan, Qatar, } \\
\text { Saudi Arabia } \\
\text { and UAE }\end{array}$ & $\begin{array}{l}2002- \\
2010\end{array}$ & $\begin{array}{l}\text { Yearly bank- } \\
\text { level } \\
\text { accounting } \\
\text { data }\end{array}$ & $\begin{array}{l}\text { Profit efficiency } \\
\text { and default risk }\end{array}$ & $\begin{array}{l}\text { Stochastic } \\
\text { Frontier } \\
\text { Analysis and } \\
\text { distance to } \\
\text { default } \\
\text { (Merton) model }\end{array}$ & $\begin{array}{l}\text { Profit efficiency is inversely } \\
\text { related to default risk for Islamic } \\
\text { banks, whereas for conventional } \\
\text { banks it is positively linked }\end{array}$ \\
\hline $\begin{array}{l}\text { Mollah et al } \\
(2014)\end{array}$ & $\begin{array}{l}\text { Bahrain, } \\
\text { Bangladesh, } \\
\text { Malaysia, } \\
\text { Pakistan, Saudi } \\
\text { Arabia, The } \\
\text { United Arab } \\
\text { Emirates, and } \\
\text { The United } \\
\text { Kingdom }\end{array}$ & $\begin{array}{l}2006- \\
2009\end{array}$ & $\begin{array}{l}\text { Yearly bank- } \\
\text { level } \\
\text { accounting } \\
\text { data }\end{array}$ & $\begin{array}{l}\text { Links between } \\
\text { risk exposure, } \\
\text { governance } \\
\text { indicators and } \\
\text { bank } \\
\text { performance/value }\end{array}$ & PLS and GMM & $\begin{array}{l}\text { Corporate governance (CGI) and } \\
\text { financial disclosure (FDTI) indices } \\
\text { have emerged as the key driving } \\
\text { forces for risk-taking for Islamic } \\
\text { banks. Shariá boards do not inhibit } \\
\text { risk-taking }\end{array}$ \\
\hline
\end{tabular}

Source: Adapted from Abedifar et al (2013) Table 1 and authors updates 
Table 3 Other Islamic Banking Issues

\begin{tabular}{|c|c|c|c|c|c|c|}
\hline Authors & $\begin{array}{l}\text { Country(ies) } \\
\text { of Study }\end{array}$ & Period & Data Type & Research Focus & Methodology & Main Finding \\
\hline Chong and Liu (2009) & Malaysia & $\begin{array}{l}1995: 04 \\
- \\
2004: 04\end{array}$ & $\begin{array}{l}\text { Monthly interest } \\
\text { rates (rates of } \\
\text { return for } \\
\text { Islamic banks) }\end{array}$ & $\begin{array}{l}\text { Causality } \\
\text { relationship } \\
\text { between } \\
\text { Islamic banks } \\
\text { deposits rates } \\
\text { and interest } \\
\text { rates in } \\
\text { conventional } \\
\text { banking. }\end{array}$ & Granger causality test & $\begin{array}{l}\text { Rates of return on the } \\
\text { investment deposits of } \\
\text { Islamic banks are } \\
\text { closely related to rates } \\
\text { on conventional banks' } \\
\text { deposits. }\end{array}$ \\
\hline Imam and Kpodar (2010) & 117 countries & $\begin{array}{l}1992- \\
2006\end{array}$ & $\begin{array}{l}\text { Country level } \\
\text { data }\end{array}$ & $\begin{array}{l}\text { Determinants of } \\
\text { the diffusion of } \\
\text { Islamic banking }\end{array}$ & Regression - Tobit & $\begin{array}{l}\text { Probability for Islamic } \\
\text { banking to develop in a } \\
\text { country rises with the } \\
\text { share of the Muslim } \\
\text { population, income per } \\
\text { capita, and whether the } \\
\text { country is a net } \\
\text { exporter of oil. } \\
\text { Increasing interest rates } \\
\text { limit the diffusion of } \\
\text { Islamic banking. }\end{array}$ \\
\hline Turk Ariss (2010) & 13 countries & $\begin{array}{l}2000- \\
2006\end{array}$ & $\begin{array}{l}58 \text { Islamic and } \\
192 \text { conventional } \\
\text { banks. Yearly } \\
\text { bank accounting } \\
\text { data from } \\
\text { Bankscope }\end{array}$ & $\begin{array}{l}\text { Competitive } \\
\text { conditions in } \\
\text { banking } \\
\text { markets }\end{array}$ & $\begin{array}{l}\text { Measures of concentration, } \\
\text { Panzar Rosse H-statistic and } \\
\text { Lerner index (market power) }\end{array}$ & $\begin{array}{l}\text { Islamic banks are less } \\
\text { competitive compared } \\
\text { to conventional banks }\end{array}$ \\
\hline $\begin{array}{l}\text { Ongena and Şendeniz-Yüncü } \\
\text { (2011) }\end{array}$ & Turkey & 2008 & $\begin{array}{l}\text { Bank-firm } \\
\text { relationships }\end{array}$ & $\begin{array}{l}\text { Firm bank } \\
\text { choice }\end{array}$ & Multinomial logit & $\begin{array}{l}\text { Islamic banks mainly } \\
\text { have corporate clients } \\
\text { that are young, } \\
\text { transparent, industry- } \\
\text { focused, and have } \\
\text { multiple-bank } \\
\text { relationships. }\end{array}$ \\
\hline Weill (2011) & $\begin{array}{l}17 \text { OIC } \\
\text { member } \\
\text { countries }\end{array}$ & $\begin{array}{l}2001- \\
2007\end{array}$ & $\begin{array}{l}\text { Yearly bank- } \\
\text { level accounting } \\
\text { data }\end{array}$ & Market power & $\begin{array}{l}\text { Regression - random effects } \\
\text { GLS }\end{array}$ & $\begin{array}{l}\text { Islamic banks have } \\
\text { lower market power } \\
\text { than conventional } \\
\text { banks. }\end{array}$ \\
\hline Aysan et al (2014) & Turkey & $\begin{array}{l}2004: 03- \\
2012: 12\end{array}$ & Deposit data & $\begin{array}{l}\text { Behavioral } \\
\text { aspects of } \\
\text { Islamic bank } \\
\text { depositors in a } \\
\text { dual banking } \\
\text { system }\end{array}$ & $\begin{array}{l}\text { Panel vector autoregression } \\
\text { (panel-VAR) }\end{array}$ & $\begin{array}{l}\text { Conventional bank } \\
\text { depositors are relatively } \\
\text { less sensitive to interest } \\
\text { rate changes compared } \\
\text { to } \\
\text { Islamic bank depositors } \\
\text { since only the largest } \\
\text { depositor groups are } \\
\text { found to be } \\
\text { significantly } \\
\text { responsive to interest } \\
\text { rate shocks }\end{array}$ \\
\hline Hassan et al (2014) & $\begin{array}{l}55 \text { OIC } \\
\text { countries }\end{array}$ & $\begin{array}{l}1990- \\
2011\end{array}$ & $\begin{array}{l}\text { Financial } \\
\text { inclusion } \\
\text { indicators (e.g. } \\
\text { ATM usage) and } \\
\text { GDP growth } \\
\text { measures }\end{array}$ & $\begin{array}{l}\text { Examines the } \\
\text { relationship } \\
\text { between } \\
\text { financial } \\
\text { inclusion and } \\
\text { economic } \\
\text { development in } \\
\text { Islamic } \\
\text { economies } \\
\end{array}$ & $\begin{array}{l}\text { Panel VAR, forecast error } \\
\text { variance decompositions, } \\
\text { Panel Granger causality tests }\end{array}$ & $\begin{array}{l}\text { Financial inclusion has } \\
\text { a positive link to } \\
\text { economic development } \\
\text { and the relationship } \\
\text { varies across regions. }\end{array}$ \\
\hline Shaban, et al (2014) & Indonesia & $\begin{array}{l}2002- \\
2010\end{array}$ & $\begin{array}{l}\text { Data on small } \\
\text { business lending } \\
\text { and other } \\
\text { financial data on } \\
107 \text { conventional } \\
\text { banks and } 7 \\
\text { Islamic banks. } \\
\text { Data from the } \\
\text { Central Bank of } \\
\text { Indonesia }\end{array}$ & $\begin{array}{l}\text { Determinants of } \\
\text { small business } \\
\text { lending }\end{array}$ & $\begin{array}{l}\text { Dynamic GMM and Granger } \\
\text { causality tests }\end{array}$ & $\begin{array}{l}\text { Small and more } \\
\text { profitable banks are } \\
\text { more likely to focus on } \\
\text { small business lending. } \\
\text { Islamic banks also have } \\
\text { a higher proportion of } \\
\text { small business lending } \\
\text { on their books from } \\
\text { which they earn } \\
\text { relatively high margins }\end{array}$ \\
\hline
\end{tabular}




\begin{tabular}{|c|c|c|c|c|c|c|}
\hline Mallin et al (2014) & $\begin{array}{l}13 \text { countries } \\
\text { - Bahrain, } \\
\text { Bangladesh, } \\
\text { Indonesia, } \\
\text { Jordan, } \\
\text { Kuwait, } \\
\text { Malaysia, } \\
\text { Pakistan, } \\
\text { Qatar, Saudi } \\
\text { Arabia, } \\
\text { Sudan, Syria, } \\
\text { UAE and } \\
\text { UK. }\end{array}$ & $\begin{array}{l}2010- \\
2011\end{array}$ & $\begin{array}{l}\text { Constructs a } \\
\text { corporate social } \\
\text { responsibility } \\
\text { (CSR) disclosure } \\
\text { index }\end{array}$ & $\begin{array}{l}\text { Examines the } \\
\text { relationship } \\
\text { between } \\
\text { Islamic bank } \\
\text { CSR disclosure } \\
\text { and the features } \\
\text { of the Shariá } \\
\text { Supervisory } \\
\text { Board on bank } \\
\text { performance }\end{array}$ & OLS and 3SLS & $\begin{array}{l}\text { Positive link } \\
\text { between CSR disclosure } \\
\text { and performance. There } \\
\text { is also a positive and } \\
\text { highly significant link } \\
\text { between the Shariá } \\
\text { supervisory board } \\
(S S B) \text { size } \\
\text { and } C S R \text { disclosure } \\
\text { index. }\end{array}$ \\
\hline Elnahass et al (2014) & $\begin{array}{l}\text { Middle East } \\
\text { North Africa } \\
\text { (MENA) } \\
\text { countries }\end{array}$ & $\begin{array}{l}2006- \\
2011\end{array}$ & $\begin{array}{l}74 \text { Conventional } \\
\text { and } 32 \text { Islamic } \\
\text { banks }\end{array}$ & $\begin{array}{l}\text { Looks at the } \\
\text { link between } \\
\text { loan loss } \\
\text { provisioning } \\
\text { (LLP) and } \\
\text { value creation }\end{array}$ & Fixed effects regression & $\begin{array}{l}\text { LLP has positive value } \\
\text { relevance to investors } \\
\text { in both banking sectors. } \\
\text { Investors } \\
\text { in Islamic banks price } \\
\text { the discretionary } \\
\text { component relatively } \\
\text { lower than their } \\
\text { conventional } \\
\text { counterparts }\end{array}$ \\
\hline Gheeraert (2014) & 55 countries & $\begin{array}{l}2000- \\
2005\end{array}$ & $\begin{array}{l}\text { Aggregate data } \\
\text { on banking and } \\
\text { financial sector } \\
\text { development. } \\
\text { Data from the } \\
\text { World bank's } \\
\text { Financial } \\
\text { structure } \\
\text { database }\end{array}$ & $\begin{array}{l}\text { Examines the } \\
\text { link between } \\
\text { Islamic banking } \\
\text { and aggregate } \\
\text { banking sector } \\
\text { development }\end{array}$ & Regression & $\begin{array}{lr}\text { Islamic banking } & \text { sector } \\
\text { developments } & \text { aids } \\
\text { overall banking } & \text { sector } \\
\text { development } & \end{array}$ \\
\hline Gheeraert and Weill (2014) & 70 countries & $\begin{array}{l}2000- \\
2005\end{array}$ & $\begin{array}{l}\text { Yearly bank- } \\
\text { level accounting } \\
\text { data and macro } \\
\text { data }\end{array}$ & $\begin{array}{l}\text { Examines } \\
\text { Islamic banking } \\
\text { development } \\
\text { and } \\
\text { macroeconomic } \\
\text { efficiency }\end{array}$ & Stochastic Frontier Analysis & 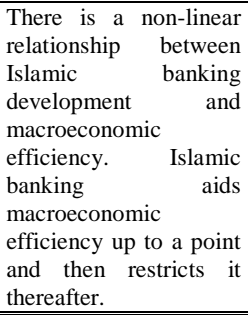 \\
\hline Abedifar et al. (2014) & 22 Countries & $\begin{array}{l}1999- \\
2009\end{array}$ & $\begin{array}{l}\text { Bank-level } \\
\text { obtained from } \\
\text { the Bankscope } \\
\text { and Country- } \\
\text { level data } \\
\text { collected from } \\
\text { the World Bank } \\
\text { database. }\end{array}$ & $\begin{array}{l}\text { Finance-growth } \\
\text { nexus }\end{array}$ & Regression & $\begin{array}{l}\text { Presence of Islamic } \\
\text { banks is positively } \\
\text { linked to the banking } \\
\text { sector development and } \\
\text { economic growth, but } \\
\text { negatively is associated } \\
\text { with income inequality } \\
\text { and poverty. The extent } \\
\text { and modality of the } \\
\text { relationships depend } \\
\text { considerably on the } \\
\text { institutional within } \\
\text { environment a dual-banking } \\
\text { which a } \\
\text { system operates. }\end{array}$ \\
\hline
\end{tabular}


Table 4 Empirical Evidence from Islamic Finance

\begin{tabular}{|c|c|c|c|c|c|c|}
\hline Authors & Sample & Period & Data Type & Research Focus & Methodology & Main Finding \\
\hline $\begin{array}{l}\text { Ismail and } \\
\text { Shakrani } \\
(2003)\end{array}$ & $\begin{array}{l}12 \text { Islamic } \\
\text { Malaysian } \\
\text { mutual funds }\end{array}$ & $\begin{array}{l}\text { May 1999- } \\
\text { July } \\
2001\end{array}$ & $\begin{array}{l}\text { Monthly } \\
\text { mutual fund } \\
\text { returns and } \\
\text { market } \\
\text { benchmark }\end{array}$ & $\begin{array}{l}\text { Examining the } \\
\text { link between } \\
\text { market risk and } \\
\text { fund returns }\end{array}$ & $\begin{array}{l}\text { CAPM and } \\
\text { cross-sectional } \\
\text { regression }\end{array}$ & $\begin{array}{l}\text { Beta explained most of the } \\
\text { variation in Islamic fund returns }\end{array}$ \\
\hline $\begin{array}{l}\text { Elfakhani et } \\
\text { al (2005) }\end{array}$ & $\begin{array}{l}46 \text { Islamic } \\
\text { mutual funds }\end{array}$ & $\begin{array}{l}\text { January 1, } \\
1997 \text {, and } \\
\text { ends on } \\
\text { August } 31 \text {, } \\
2002\end{array}$ & $\begin{array}{l}\text { Mutual fund } \\
\text { monthly } \\
\text { returns from } \\
\text { Failaka } \\
\text { International } \\
\text { and Standard } \\
\text { \& Poor's }\end{array}$ & $\begin{array}{l}\text { Comparing the } \\
\text { performance of } \\
\text { Islamic mutual } \\
\text { funds with } \\
\text { conventional } \\
\text { equity } \\
\text { benchmarks } \\
\text { also at market } \\
\text { timing and } \\
\text { selectivity } \\
\text { issues }\end{array}$ & $\begin{array}{l}\text { Sharpe, } \\
\text { Treynor,, } \\
\text { Jensen ratios } \\
\text { plus the } \\
\text { Mazury (TM) } \\
\text { model }\end{array}$ & $\begin{array}{l}\text { There is no statistically } \\
\text { significant risk-adjusted } \\
\text { abnormal reward or penalty } \\
\text { associated with investing in } \\
\text { Sharia compliant mutual funds }\end{array}$ \\
\hline Hayat (2006) & $\begin{array}{l}59 \text { (Malaysian } \\
\text { and } \\
\text { International) }\end{array}$ & $\begin{array}{l}\text { August 2001- } \\
\text { August } 2006\end{array}$ & $\begin{array}{l}\text { Fund weekly } \\
\text { returns from } \\
\text { Bloomberg }\end{array}$ & $\begin{array}{l}\text { Comparing } \\
\text { return / risk } \\
\text { performance } \\
\text { against } \\
\text { conventional } \\
\text { and Islamic } \\
\text { benchmarks }\end{array}$ & $\begin{array}{l}\text { Sharpe, CAPM } \\
\text { Jensen Alpha, } \\
\text { Timing and } \\
\text { Mazury (TM) } \\
\text { model }\end{array}$ & $\begin{array}{l}\text { Islamic fund do not significantly } \\
\text { under or outperform their } \\
\text { Islamic as well as conventional } \\
\text { benchmarks under normal } \\
\text { market conditions. During the } \\
\text { bear market of } 2002 \\
\text { Islamic funds did however } \\
\text { significantly outperform the } \\
\text { Islamic and conventional market }\end{array}$ \\
\hline $\begin{array}{l}\text { Abdullah et al } \\
(2007)\end{array}$ & $\begin{array}{l}65 \text { Malaysian } \\
\text { funds, } 14 \text { of } \\
\text { which are } \\
\text { Islamic funds }\end{array}$ & $\begin{array}{l}\text { January } 1992 \\
\text { through } \\
\text { December } \\
2001 .\end{array}$ & $\begin{array}{l}\text { Mutual fund } \\
\text { monthly } \\
\text { returns from }\end{array}$ & $\begin{array}{l}\text { Comparing the } \\
\text { performance of } \\
\text { Islamic mutual } \\
\text { funds with } \\
\text { conventional } \\
\text { equity } \\
\text { benchmarks }\end{array}$ & $\begin{array}{l}\text { Sharpe, } \\
\text { Jensen Alpha, } \\
\text { Timing and } \\
\text { selectivity } \\
\text { ability }\end{array}$ & $\begin{array}{l}\text { Islamic funds performed better } \\
\text { than the conventional funds } \\
\text { during bearish economic trends } \\
\text { while, conventional funds } \\
\text { showed better } \\
\text { performance than Islamic funds } \\
\text { during bullish economic } \\
\text { conditions }\end{array}$ \\
\hline Ferdian and & 20 Malaysia & $\begin{array}{l}1 \text { October } \\
2005-\end{array}$ & $\begin{array}{l}\text { Monthly } \\
\text { returns }\end{array}$ & $\begin{array}{l}\text { Comparing } \\
\text { returns with the }\end{array}$ & $\begin{array}{l}\text { Treynor, } \\
\text { Sharpe and }\end{array}$ & $\begin{array}{l}\text { Malaysian Islamic funds } \\
\text { outperform Indonesian Islamic }\end{array}$ \\
\hline Dewi (2007) & $\begin{array}{l}5 \text { Indonesian } \\
\text { Islamic Funds }\end{array}$ & 30 April 2007 & $\begin{array}{l}\text { obtained from } \\
\text { Bloomberg }\end{array}$ & $\begin{array}{l}\text { market and } \\
\text { Islamic indexes }\end{array}$ & $\begin{array}{l}\text { Jensen } \\
\text { measures }\end{array}$ & $\begin{array}{l}\text { Funds. Islamic mutual funds } \\
\text { relatively outperform the market }\end{array}$ \\
\hline $\begin{array}{l}\text { Cakir and } \\
\text { Raei (2007) }\end{array}$ & $\begin{array}{l}\text { Sovereign and } \\
\text { conventional } \\
\text { bond issues in } \\
\text { international } \\
\text { markets by } \\
\text { Malaysia, } \\
\text { Pakistan, } \\
\text { Qatar, and } \\
\text { Bahrain. }\end{array}$ & $\begin{array}{l}\text { Date of issue } \\
\text { to end-June } \\
2007\end{array}$ & $\begin{array}{l}\text { Daily and } \\
\text { Weekly price } \\
\text { data. } \\
\text { DataStream } \\
\text { for } \\
\text { Malaysian, } \\
\text { Pakistani, and } \\
\text { Qatari bonds. } \\
\text { Bloomberg } \\
\text { for Bahrain }\end{array}$ & $\begin{array}{l}\text { Assesses the } \\
\text { impact of } \\
\text { issuance of } \\
\text { Sukuk on } \\
\text { the cost and risk } \\
\text { structure of } \\
\text { investment } \\
\text { portfolios }\end{array}$ & $\begin{array}{l}\text { Value-at-Risk } \\
\text { (VaR) } \\
\text { measures. } \\
\text { Delta-normal } \\
\text { and Monte } \\
\text { Carlo } \\
\text { simulation }\end{array}$ & $\begin{array}{l}\text { Correlations of Sukuk returns } \\
\text { with returns on conventional } \\
\text { bonds are much smaller than the } \\
\text { correlations of returns on } \\
\text { conventional bonds with each } \\
\text { other. They can provide } \\
\text { portfolio diversification benefits }\end{array}$ \\
\hline $\begin{array}{l}\text { Abderrezak } \\
(2008)\end{array}$ & $\begin{array}{l}46 \\
\text { International } \\
\text { Islamic funds }\end{array}$ & $\begin{array}{l}\text { January 1997- } \\
\text { August } 2002\end{array}$ & $\begin{array}{l}\text { Monthly } \\
\text { returns }\end{array}$ & $\begin{array}{l}\text { Comparing } \\
\text { returns with the } \\
\text { market and } \\
\text { Islamic indexes } \\
\text { and } \\
\text { conventional } \\
\text { funds }\end{array}$ & $\begin{array}{l}\text { Sharpe, Fama } \\
\text { and 3-factor } \\
\text { Fama and } \\
\text { French model. } \\
\text { Selectivity and } \\
\text { timing }\end{array}$ & $\begin{array}{l}\text { No significant performance } \\
\text { difference between Islamic and } \\
\text { conventional funds. Islamic and } \\
\text { conventional funds did not } \\
\text { outperform the SP500 }\end{array}$ \\
\hline $\begin{array}{l}\text { Derigs } \\
\text { and Marzban } \\
(2009)\end{array}$ & $\begin{array}{l}\text { Assets included } \\
\text { in the } \\
\text { S\& P } 500 \\
\text { index }\end{array}$ & $\begin{array}{l}\text { S\&P500 index } \\
\text { on the } \\
17 / 9 / 2007 \text { and } \\
\text { company data } \\
\text { from } 2006\end{array}$ & $\begin{array}{l}\text { Monthly } \\
\text { Index and } \\
\text { company } \\
\text { returns from } \\
\text { Bloomberg }\end{array}$ & $\begin{array}{l}\text { Simulating } \\
\text { various types of } \\
\text { Shariá } \\
\text { compliant } \\
\text { portfolios }\end{array}$ & $\begin{array}{l}\text { Portfolio } \\
\text { simulation }\end{array}$ & $\begin{array}{l}\text { Shariá -compliant portfolios can } \\
\text { be constructed that have return } \\
\text { and risk profiles comparable to } \\
\text { conventional non-constrained } \\
\text { portfolios }\end{array}$ \\
\hline $\begin{array}{l}\text { Haddad et al } \\
\text { (2009) }\end{array}$ & $\begin{array}{l}46 \\
\text { International } \\
\text { Islamic funds }\end{array}$ & $\begin{array}{l}\text { January 1997- } \\
\text { August } 2002\end{array}$ & $\begin{array}{l}\text { Monthly } \\
\text { returns }\end{array}$ & $\begin{array}{l}\text { Examine } \\
\text { systematic risk } \\
\text { and fund returns } \\
\text { relating to } \\
\text { S\&P500 and FT } \\
\text { Global Islamic } \\
\text { index }\end{array}$ & $\begin{array}{l}\text { Single factor } \\
\text { Schwert and } \\
\text { Seguin model }\end{array}$ & $\begin{array}{l}\text { Islamic mutual funds are similar } \\
\text { to conventional funds. Volatility } \\
\text { persistence is affected by the } \\
\text { market proxy. }\end{array}$ \\
\hline $\begin{array}{l}\text { Saad et al } \\
(2010)\end{array}$ & $\begin{array}{l}27 \text { Malaysian } \\
\text { funds of which } \\
5 \text { are Islamic }\end{array}$ & $2002-2005$ & $\begin{array}{l}\text { Input and } \\
\text { Output } \\
\text { measures } \\
\text { (returns are } \\
\text { an output) }\end{array}$ & $\begin{array}{l}\text { Examines the } \\
\text { efficiency and } \\
\text { productivity } \\
\text { (Malmquist) of } \\
\text { the funds } \\
\text { industry in } \\
\text { Malaysia }\end{array}$ & $\begin{array}{l}\text { Data } \\
\text { Envelopment } \\
\text { Analysis } \\
\text { (DEA) }\end{array}$ & $\begin{array}{l}\text { Some of the Islamic funds are } \\
\text { more efficient than their } \\
\text { conventional counterparts }\end{array}$ \\
\hline
\end{tabular}




\begin{tabular}{|c|c|c|c|c|c|c|}
\hline $\begin{array}{l}\text { Godlewski et } \\
\text { al (2011) }\end{array}$ & $\begin{array}{l}170 \text { Malaysian } \\
\text { bond issues of } \\
\text { which } 77 \text { are } \\
\text { Sukuk and } \\
93 \\
\text { conventional } \\
\text { bonds }\end{array}$ & $2002-2009$ & $\begin{array}{l}\text { Date of } \\
\text { issuance and } \\
\text { closing stock } \\
\text { price of } \\
\text { companies } \\
\text { issuing debt } \\
\text { (from } \\
\text { Bloomberg) }\end{array}$ & $\begin{array}{l}\text { Impact of } \\
\text { conventional } \\
\text { bonds and } \\
\text { Sukuk } \\
\text { announcements } \\
\text { on market }\end{array}$ & $\begin{array}{l}\text { Market model } \\
\text { event study }\end{array}$ & $\begin{array}{l}\text { No significant stock-market } \\
\text { reaction to conventional bond } \\
\text { announcements, a negative } \\
\text { reaction to Sukuk issues and } \\
\text { significant difference in stock } \\
\text { market reactions to Sukuk and } \\
\text { conventional bond issues. }\end{array}$ \\
\hline $\begin{array}{l}\text { Mansor and } \\
\text { Bhatti } \\
(2011)\end{array}$ & $\begin{array}{l}128 \text { Islamic } \\
\text { and } 350 \\
\text { conventional } \\
\text { Malaysian } \\
\text { funds }\end{array}$ & $\begin{array}{l}\text { January } 1995- \\
\text { December } \\
1998 \text { and } \\
\text { January 2005- } \\
\text { December } \\
2008\end{array}$ & $\begin{array}{l}\text { Monthly } \\
\text { returns of } \\
\text { funds from } \\
\text { Morningstar }\end{array}$ & $\begin{array}{l}\text { Examines } \\
\text { descriptive } \\
\text { statistics on } \\
\text { return and } \\
\text { volatility } \\
\text { comparing } \\
\text { conventional } \\
\text { and Islamic } \\
\text { funds } \\
\end{array}$ & $\begin{array}{l}\text { Summary } \\
\text { return and } \\
\text { volatility } \\
\text { statistics }\end{array}$ & $\begin{array}{l}\text { Islamic and conventional funds } \\
\text { outperform the market return } \\
\text { Islamic funds are more risky } \\
\text { than conventional Malaysian } \\
\text { funds }\end{array}$ \\
\hline \multirow[t]{2}{*}{$\begin{array}{l}\text { Hayat and } \\
\text { Kraeussl } \\
(2011)\end{array}$} & \multirow[t]{2}{*}{$\begin{array}{l}145 \text { Islamic } \\
\text { equity funds }\end{array}$} & \multirow{2}{*}{$\begin{array}{l}\text { January } 2000 \\
\text { to February } \\
2009\end{array}$} & \multirow[t]{2}{*}{$\begin{array}{l}\text { Weekly } \\
\text { returns }\end{array}$} & \multirow{2}{*}{$\begin{array}{l}\text { Comparing } \\
\text { return / risk } \\
\text { performance } \\
\text { against } \\
\text { conventional } \\
\text { and Islamic } \\
\text { benchmarks }\end{array}$} & \multirow[t]{2}{*}{$\begin{array}{l}\text { CAPM and } \\
\text { investigating } \\
\text { market timing }\end{array}$} & \multirow{2}{*}{$\begin{array}{l}\text { Islamic equity funds } \\
\text { underperform compared to } \\
\text { Islamic as well as to } \\
\text { conventional } \\
\text { benchmarks. } \\
\text { Underperformance seems to } \\
\text { have increased during the } \\
2007 / 8 \text { financial crisis. }\end{array}$} \\
\hline & & & & & & \\
\hline $\begin{array}{l}\text { Hoepner et al } \\
\text { (2011) }\end{array}$ & $\begin{array}{l}265 \text { Islamic } \\
\text { equity funds } \\
\text { from } 20 \\
\text { countries }\end{array}$ & $\begin{array}{l}\text { September } \\
1990 \text { - April } \\
2009 \text {. }\end{array}$ & $\begin{array}{l}\text { Mutual fund } \\
\text { monthly } \\
\text { returns and } \\
\text { related data } \\
\text { from } \\
\text { Eurekahedge }\end{array}$ & $\begin{array}{l}\text { Comparing } \\
\text { Islamic fund } \\
\text { performance } \\
\text { and investment } \\
\text { style with an } \\
\text { array of } \\
\text { conventional } \\
\text { benchmarks }\end{array}$ & $\begin{array}{l}\text { CAPM and } \\
\text { Carhart models }\end{array}$ & $\begin{array}{l}\text { No strong evidence that Islamic } \\
\text { funds in general under- or } \\
\text { outperform equity markets. } \\
\text { National characteristics explain } \\
\text { the heterogeneity in Islamic fund } \\
\text { performance. Islamic funds from } \\
\text { the GCC and Malaysia perform } \\
\text { competitively or even } \\
\text { outperform international equity } \\
\text { market benchmarks. }\end{array}$ \\
\hline $\begin{array}{l}\text { Razzaq et al } \\
\text { (2012) }\end{array}$ & $\begin{array}{l}9 \text { Pakistan } \\
\text { Islamic funds }\end{array}$ & $2009-2010$ & Daily returns & $\begin{array}{l}\text { Case study on } \\
\text { the performance } \\
\text { of nine funds }\end{array}$ & $\begin{array}{l}\text { Sharpe, } \\
\text { Treynor, } \\
\text { Jensens alpha }\end{array}$ & $\begin{array}{l}\text { Returns on Islamic funds are } \\
\text { risk related }\end{array}$ \\
\hline $\begin{array}{l}\text { Białkowski et } \\
\text { al } \\
(2012)\end{array}$ & $\begin{array}{l}\text { Countries } \\
\text { where the } \\
\text { proportion of } \\
\text { Muslim } \\
\text { population } \\
\text { exceeded } 50 \% \\
-14 \text { countries }\end{array}$ & $\begin{array}{l}\text { 1994-2006 } \\
\text { (Various for } \\
\text { different } \\
\text { countries) }\end{array}$ & $\begin{array}{l}\text { Stock market } \\
\text { index data } \\
\text { from } \\
\text { Datastream }\end{array}$ & $\begin{array}{l}\text { Event study on } \\
\text { the impact of } \\
\text { Ramadan }\end{array}$ & $\begin{array}{l}\text { Market model, } \\
\text { event study }\end{array}$ & $\begin{array}{l}\text { Stock returns during Ramadan } \\
\text { are significantly higher and less } \\
\text { volatile than during the rest of } \\
\text { the year. No declines in market } \\
\text { liquidity are recorded }\end{array}$ \\
\hline $\begin{array}{l}\text { Alam et al } \\
(2013)\end{array}$ & $\begin{array}{l}79 \text { Sukuks and } \\
87 \\
\text { conventional } \\
\text { bonds from } \\
\text { Malaysia, } \\
\text { Indonesia, } \\
\text { Singapore, } \\
\text { Pakistan, UAE, } \\
\text { Bahrain and } \\
\text { Qatar }\end{array}$ & 2004-2012 & $\begin{array}{l}\text { Closing stock } \\
\text { prices for } \\
\text { firms } \\
\text { issuing debt } \\
\text { from } \\
\text { Bloomberg }\end{array}$ & $\begin{array}{l}\text { Impact of } \\
\text { conventional } \\
\text { bonds and } \\
\text { Sukuk } \\
\text { announcements } \\
\text { on shareholder } \\
\text { wealth }\end{array}$ & $\begin{array}{l}\text { Market model } \\
\text { event study }\end{array}$ & $\begin{array}{l}\text { Negative market reaction for the } \\
\text { announcements of Sukuk issues } \\
\text { before and during } 2007 \text { global } \\
\text { financial crisis. }\end{array}$ \\
\hline $\begin{array}{l}\text { Abdelsalama } \\
\text { et al (2014) }\end{array}$ & $\begin{array}{l}138 \text { Islamic } \\
\text { funds and } 636 \\
\text { socially } \\
\text { responsible } \\
\text { funds }\end{array}$ & $\begin{array}{l}\text { January, 1989, } \\
\text { until } \\
\text { March,2011, }\end{array}$ & $\begin{array}{l}\text { Input and } \\
\text { output fund } \\
\text { measures }\end{array}$ & $\begin{array}{l}\text { Efficiency } \\
\text { analysis } \\
\text { comparing } \\
\text { Islamic with } \\
\text { social } \\
\text { responsible } \\
\text { mutual funds }\end{array}$ & $\begin{array}{l}\text { Non-parametric } \\
\text { Free } \\
\text { Disposable } \\
\text { Hull (FDH) } \\
\text { efficiency } \\
\text { analysis and } \\
\text { second stage } \\
\text { quantile } \\
\text { regression }\end{array}$ & $\begin{array}{l}\text { The average efficiency of } \\
\text { socially responsible (SRI) funds } \\
\text { is slightly higher than that of } \\
\text { Islamic funds. }\end{array}$ \\
\hline $\begin{array}{l}\text { Azmat et al } \\
(2014)\end{array}$ & Malaysian & $\begin{array}{l}2002- \\
2010\end{array}$ & $\begin{array}{l}\text { Islamic bond } \\
\text { issuers from } \\
\text { the IFIS data } \\
\text { base. }\end{array}$ & $\begin{array}{l}\text { Evaluation of the } \\
\text { credit risk of } \\
\text { Islamic }(S u k u k) \\
\text { bonds }\end{array}$ & $\begin{array}{l}\text { Survival } \\
\text { probability } \\
\text { simulation }\end{array}$ & $\begin{array}{l}\text { Traditional credit risk } \\
\text { methodologies underestimate the } \\
\text { survival risk of Islamic bonds, or } \\
\text { to put another way, they rate them } \\
\text { as higher credit risk. }\end{array}$ \\
\hline $\begin{array}{l}\text { Abdelsalama } \\
\text { et al (2014) }\end{array}$ & $\begin{array}{l}138 \text { Islamic } \\
\text { funds and } 636 \\
\text { socially } \\
\text { responsible } \\
\text { funds }\end{array}$ & $\begin{array}{l}\text { December } \\
2000 \text { and } \\
\text { March } \\
2011\end{array}$ & $\begin{array}{l}\text { Input and } \\
\text { output fund } \\
\text { measures. } \\
\text { Simulation to } \\
\text { evaluate } \\
\text { persistence }\end{array}$ & $\begin{array}{l}\text { Analyses } \\
\text { performance } \\
\text { persistence using } \\
\text { efficiency analysis }\end{array}$ & $\begin{array}{l}\text { Non-parametric } \\
\text { Free Disposable } \\
\text { Hull (FDH) } \\
\text { efficiency } \\
\text { analysis with } \\
\text { second and } \\
\text { third stage } \\
\text { analysis }\end{array}$ & $\begin{array}{l}\text { Performance of Islamic and } \\
\text { Socially Responsible funds persist } \\
\text { but only for worst and best } \\
\text { performing funds }\end{array}$ \\
\hline
\end{tabular}

